\title{
The Pitfalls of Migration Diplomacy: The EU Pact and Relations with Third Countries
}

\author{
Elspeth Guild"
}

The term externalisation of migration control has been in circulation for more than 30 years now and includes a wide range of subjects and issues ranging from visa policies to push backs of little boats at sea. It has been the subject of substantial academic consideration ${ }^{1}$ and criticism from NGOs. ${ }^{2}$ At the heart of the notion is that migration control engages both the countries from which (unwanted) people ${ }^{3}$ leave and those where they arrive. Where those countries of entry employ diplomatic, development, financial and other tools to encourage those states from which (unwanted) people are seeking to leave to prevent their departure then the responsibility to receive them (where they claim international protection) or to expel them (where they are categorised as 'illegal' migrants, a term much disparaged by international institutions including the UN but used in EU law ${ }^{4}$ will not fall on the receiving state. This principle is central to readmission agreements among states, the earliest of which, for the EU, was with Hong

" Jean Monnet Professor ad personam, Queen Mary University of London and emeritus, Radboud University Nijmegen, Netherlands.

1 Bernard Ryan and Valsamis Mitsilegas, Extraterritorial Immigration Control (Brill Nijhoff 2010); Inka Stock, Ayşen Üstübici and Susanne U. Schultz, 'Externalization at work: responses to migration policies from the Global South' (2019) 48 Comparative Migration Studies 7.

2 For instance already in 2017 by FIHD <www.fidh.org/en/issues/migrants-rights/ the-externalization-of-migration-policies-a-scourge-for-human-rights $>$ accessed 2 November 2021.

3 Who is unwanted in the EU is a complex issue: The EU border agency, Frontex reports that annually more than 300 million entries are usually recorded into the EU. About 130,000 people are refused entry and there are usually around 150,000 irregular entries. So determining who is unwanted usually boils down to a very small number of people who are seeking entry without the required documentation; Elspeth Guild, 'Interrogating Europe's Borders: Reflections from an Academic Career' (2019).

4 Sébastien Chauvin and Blanca Garcés-Mascareñas, 'Becoming less illegal: Deservingness frames and undocumented migrant incorporation' (2014) 8.4 Sociology compass $422-432$. 
Kong in $2004^{5}$ which agreements are intended to facilitate expulsion. It is manifest in the revision of the Visa Code to include expulsion related criteria to the assessment and cost of visa applications on the basis of country of origin. ${ }^{6}$

The Global Compact for Safe Orderly and Regular Migration (the Marrakesh Compact, $(\mathrm{MC}))^{7}$ the UN's most recent instrument in the field of migration dating from 2018, specifically states that border management is a shared responsibility among states. ${ }^{8}$ Reading this responsibility through the lens of UN human rights law, upon which the Compact is expressly founded, this means a duty on states in the exercise of state sovereignty in border control to ensure the full respect and application of their human rights obligations. The emphasis on migration control as necessarily engaging the country of departure has numerous facets. Early $21^{\text {st }}$ century examples include the so-called juxtaposed controls on the UK-French border which in practice are very light touch by French border police on persons leaving the UK and very heavy handed as regards (unwanted) persons seeking to leave France towards the UK. ${ }^{9}$ So in practice, heavy border controls take place exclusively in France where in pursuit of British border exclusion policies, the French border police use force against would be migrants to prevent them from leaving France. ${ }^{10}$ This imbalance in the practices of shared responsibility which is a manifestation of extraterritorial border controls is evident in all the EU measures in pursuit of moving these controls into the jurisdiction of third countries. The consequence

5 OJ $2004 \mathrm{~L} 17 / 23$.

6 Regulation 1155/2019 (OJ 2019 L 188/55) Amending the Visa Code Regulation $810 / 2009$.

7 <www.un.org/pga/72/wp-content/uploads/sites/51/2018/07/migration.pdf $>$ accessed 4 November 2021.

8 MC para 14: "We unite, in a spirit of win-win cooperation, to address the challenges and opportunities of migration in all its dimensions through shared responsibility and innovative solutions. It is with this sense of common purpose that we take this historic step, fully aware that the Global Compact for Safe, Orderly and Regular Migration is a milestone, but not the end to our efforts."

$9<$ www.gov.uk/government/news/uk-and-france-sign-action-plan-to-tackle-small-bo at-crossings $>$ accessed 3 October 2021.

10 Sue Reid and James Franey, 'French police open fire on migrants' dinghy on Dunkirk beach with potentially lethal rubber bullets to stop their illegal boat crossing the Channel to the UK' (dailymail.co.uk, 3 October 2021) <www.dailym ail.co.uk/news/article-10050681/Horror-Dunkirk-beach-French-police-open-fire-m igrants-dinghy-rubber-bullets.html> accessed 3 October 2021. 
is violations of the international human right to leave a country. ${ }^{11}$ Externalisation practice is also problematic for the international obligation of non-refoulement - the duty on states not to send a person to a country where they fear persecution under the refugee convention ${ }^{12}$ or a real risk of torture, inhuman or degrading treatment. ${ }^{13}$ There are two strands to this source of friction for the EU: first is the country which should be preventing (unwanted) people from leaving actually a state where persecution and torture are rife including against those seeking to leave; the pressing example is Libya ${ }^{14}$ where cooperation between the EU border agency, Frontex, and the Libyan coast guard has been subject to legal challenge. ${ }^{15}$ Secondly, will the state which is supposed to be preventing people leaving actually going to provide them with such protection as international law indicate, they are entitled to, or just expel them onwards to somewhere else where their safety is not assured. The most prominent example here is Turkey. ${ }^{16}$

11 Elspeth Guild and Vladislava Stoyanova, 'The human right to leave any country: a right to be delivered' in Christian Strohal and Stefan Kieber (eds), European Yearbook on Human Rights (Cambridge University Press 2018) 373-394.

12 UN General Assembly, Convention Relating to the Status of Refugees, 28 July 1951, United Nations Treaty Series vol 189, $137<$ www.refworld.org/docid/3b e01b964.html> accessed 2 November 2021.

13 UN General Assembly, Convention Against Torture and Other Cruel, Inhuman or Degrading Treatment or Punishment, 10 December 1984, United Nations Treaty Series vol 1465, 85 <www.refworld.org/docid/3ae6b3a94.html > accessed 2 November 2021; Council of Europe, European Convention for the Protection of Human Rights and Fundamental Freedoms, as amended by Protocols Nos 11 and 14, 4 November 1950, ETS 5 <www.refworld.org/docid/3ae6b3b04.html > accessed 2 November 2021; UN General Assembly, International Convention for the Protection of All Persons from Enforced Disappearance, 20 December 2006 <www.refworld.org/ docid/47fdfaeb0.html> accessed 2 November 2021.

14 UN High Commissioner for Refugees (UNHCR), UNHCR Position on the Designations of Libya as a Safe Third Country and as a Place of Safety for the Purpose of Disembarkation Following Rescue at Sea, September $2020<$ www.refworld.org/docid /5f1edee24.html> accessed 2 November 2021.

15 UN General Assembly, Rome Statute of the International Criminal Court (last amended 2010), 17 July 1998 <www.refworld.org/docid/3ae6b3a84.html> accessed 5 October 2021; Daniel Howden, Apostolis Fotiadis and Zach Campbell, 'Revealed: the great European refugee scandal' (The Guardian, December 2020); Annick Pijnenburg and Conny Rijken, 'Playing Cat and Mouse: How Europe Evades Responsibility for its Role in Human Rights Abuses of Migrants and Refugees' in Mirjam van Reisen and others (eds), Mobile Africa: Human trafficking and the digital divide (Langaa RPCIG 2019) ch 23.

16 UNHCR, 'Legal Considerations on the Return of Asylum Seekers and Refugees from Greece to Turkey as Part of the EU-Turkey Cooperation in Tackling the 
While there has been much academic attention to both of these issues and legal challenges, it has mainly been on the basis of states' human rights obligations and international criminal law. ${ }^{17}$ Recently, however, another consideration has come into play: the instrumentalization of migration and refugee movements by transit states (such as Belarus, Libya or Turkey) towards the EU as a tool of international relations. ${ }^{18}$ Just as the EU has sought to use international relations as a means to promote border and migration control so neighbouring states have seen new opportunities in international relations to make their participation in these projects meaningful from the perspective of their own political objectives. ${ }^{19}$ While the roots of this instrumentalisation have been apparent in numerous agreements between EU states and their neighbours, such as the Italian Agreement with Ghaddafi's Libya (and subsequently), ${ }^{20}$ it is also apparent in Spanish-Moroccan relations ${ }^{21}$ and is the essence of the rather controversial EU Turkey Deal $2016^{22}$ where the EU pays Turkey substantial sums for Turkey to prevent Syrians from coming to the EU.

One of the difficulties which has emerged as a result of these policies pursued by the EU with its neighbours (and other states) for the purposes of decreasing the numbers of (unwanted) person from entering the EU is

Migration Crisis under the Safe Third Country and First Country of Asylum Concept' (2017) 29 (3) International Journal of Refugee Law 498-508; Mariana Gkliati, 'The EU-Turkey deal and the safe third country concept before the Greek asylum appeals committees' (2017) 3 (2) Movements, Journal for Critical Migration and Border Regime Studies 213-224.

17 Jari Pirjola, 'Shadows in paradise - Exploring non-refoulement as an open concept' (2007) 19 (4) International Journal of Refugee Law 639-660.

18 Georgia Papagianni, 'Forging an external EU migration policy: from externalisation of border management to a comprehensive policy?' (2013) 15 (3) European Journal of Migration and Law 283-299; Polly Pallister-Wilkins, 'Searching for accountability in EU migration-management practices' (openDemocracy, 2011).

19 Bruno Oliveira Martins and Michael Strange, 'Rethinking EU external migration policy: contestation and critique' (2019) 5 (3) Global Affairs 195-202.

20 Delphine Nakache and Jessica Losier, 'The European Union Immigration Agreement with Libya: Out of Sight, Out of Mind?' (2017) 25 E-International Relations.

21 Daniel Wunderlich, 'Differentiation and policy convergence against long odds: Lessons from implementing EU migration policy in Morocco' (2010) 15 (2) Mediterranean Politics 249-272; Hein De Haas, 'Morocco's Migration Experience: A Transitional Perspective' (2007) 45 (4) International Migration 39-70.

22 Narin Idriz, "The EU-Turkey statement or the "refugee deal": the extra-legal deal of extraordinary times?" in Dina Siegel and Veronika Nagy (eds), The Migration Crisis? (Eleven International Publishing 2017); Margarite Helena Zoeteweij and Ozan Turhan, 'Above the Law-Beneath Contempt: The End of the EU-Turkey Deal' (2017) 27 Swiss Review of International and European Law 151. 
that it has contributed to raising migration and border control from a field the responsibility of interior ministries to ones of international relations engaging foreign ministries and most specifically the European External Action Service (EEAS). The term migration diplomacy is emerging as a way of describing this change in the scope of international relations. ${ }^{23}$ Border control and migration have traditionally been responsibilities of interior ministries which are concerned with the integrity of the territory and safeguarding the people for whom the state is responsible. Thus, international relations which are the responsibility of foreign ministries, usually at loggerheads with interior ministries ${ }^{24}$ have been transformed into venues where migration, border control and visa policies are on the table for inter-state discussion about cooperation or friction. ${ }^{25}$

This change in dynamic has not gone unnoticed in the EU. In her 2021 State of the Union Address the Commission President stated that the EU is facing hybrid attacks with the aim to destabilise Europe and that this cannot be tolerated. ${ }^{26}$ This has been interpreted by twelve Member States, as set out in their letter to the European Commission's Vice-President on 7 October $2021^{27}$ as meaning that "Europe is being destabilised by the instrumentalisation of 'illegal' immigration by State actors." Their solution to the problem is that the EU must use all operational, legal, diplomatic and financial tools to punish such states. The veiled accusation is that some states, first in line for these states are Belarus ${ }^{28}$ but Turkey is a close

23 Fiona B. Adamson and Gerasimos Tsourapas, 'Migration diplomacy in world politics' (2019) 20 (2) International Studies Perspectives 113-128; Gerasimos Tsourapas, 'Migration diplomacy in the Global South: cooperation, coercion and issue linkage in Gaddafi's Libya' (2017) 38 (10) Third World Quarterly 2367-85.

24 Virginie Guiraudon, 'The constitution of a European immigration policy domain: a political sociology approach' (2003) 10 (2) Journal of European public policy 263-282.

25 Didier Bigo, Foreigners, refugees or minorities?: Rethinking people in the context of border controls and visas (Routledge 2016); Sandra Lavenex and Flavia Jurje, 'EU/US migration policy towards emerging countries: regulatory power reversed?' (2017) 22 Spec European Foreign Affairs Review.

26 Ursula von der Leyen, European Commission President, 'Opening address: Europe in a changing world' (2021).

27 <www.statewatch.org/media/2859/eu-12-ms-joint-letter-hybrid-attacks-pushbacks-e u-law-7-10-21.pdf $>$ accessed 2 November 2021.

28 Oxford Analytica, 'Lithuania will try to fend off migrants from Belarus' (Emerald Expert Briefings, 2021) <www.emerald.com/insight/content/doi/10.1108/OXAN -DB263335/full/html> accessed 18 November 2021. 
contender ${ }^{29}$ are pushing people (but not their own nationals) towards their common borders with the EU for the purpose of causing political panic in EU states about irregular migration. These EU states consider that this is a threat of state sponsored irregular migration.

Two aspects are particularly important to any analysis of this turn of international politics to the EU's disadvantage. First, the EU maintains a very strong discourse on its adherence to international human rights law and the implementation of its own Charter of Fundamental Rights. Both international and EU law require EU states to respect the principle of non-refoulement, that is that no one seeking international protection can be sent to a country where his or her safety is at risk. In order to comply with the non-refoulement obligation, state authorities need to make an individual assessment of each and every international protection claim which they receive and make an objectively justifiable decision. Negative decisions must carry a right of appeal which has suspensive effect - the individual cannot be expelled while the appeal is pending. Most Member States have developed their asylum systems sufficiently, complying with EU law on reception conditions, registration and access to procedures for asylum determination, appeal rights etc. But a substantial number either have failed to do so, most spectacularly Greece, ${ }^{30}$ but including most of the signatory states of the 7 October 2021 letter or are very reluctant to comply with these rules and seek to change them (eg Denmark). For these states, externalisation is the desired solution - other states to receive and care for refugees, not them. But in seeking to achieve this objective for these states, the EU External Action Service has taken questionable action (see below) and the EU Member States have entered into non binding agreements with the exchange of eye watering amounts of money with neighbours such as Turkey to prevent arrivals. All of this is of dubious consistency with human rights commitments and the EU Charter.

So it is not surprising that many countries have noticed the efficacy of using the border control migration tool in international relations with the EU for their own benefit. Instead of simply complying with EU injunctions to prevent (unwanted) people from embarking for EU destinations

29 Roderick Parkes, 'Migration, borders and the EU's geopolitics' (14 October 2020) $<$ https://dgap.org/en/research/publications/migration-borders-and-eus-geopolitics> accessed 18 November 2021; Heaven Crawley, 'The politics of refugee protection in a post-covid-19 world' (2021) 10 (3) Social Sciences 81.

30 Angeliki Dimitriadi and Antonia-Maria Sarantaki, 'National report on the governance of the asylum reception system in Greece' (2019) 20 Ceaseval Research on the Common European Asylum System. 
(with dubious consistency with international law and the right to leave) they can exact from the EU better deals on financing, development, you name it, by playing on EU fears of (unwanted) arrivals. To make the threat real, it would seem, according to some press reports that some of these states, in particular Belarus, are blatantly doing so apparently by promoting and some EU states like Lithuania are building walls and calling for common action. ${ }^{31}$ No one is suggesting however that Lukashenko's Belarus is a particularly safe country for Afghan refugees..$^{32}$

Thus the EU finds itself between a rock and a hard place as regards the externalisation of border and migration controls. On the one hand, it has incorporated border and migration control as a central element of its external action with the objective of ensuring that non-EU states prevent movement of unwanted people towards the EU and making this a very interesting economic proposal for them, and on the other hand upholding its claim to the highest standards of human rights and fundamental rights protection including in the area of asylum, border crossing and migration. The tension between the two objectives has rattled on for some time but the transition of regime in Afghanistan and the apparent opportunity to assist Afghan refugees to get to Europe perceived by the Belarus government has torn this delicate and incompatible co-existence apart.

\section{The EU's Image as regards Fundamental Rights and Migration/Asylum}

The most pressing problem for the EU as regards working with other countries and international partners on migration and asylum is the EU's own image in this area. International media around the world extensively covered the 2015-16 refugee arrivals into the EU, revealing the appalling conditions of arrival and first 'reception' which pushed almost 2 million people in desperate need of refuge and assistance to walk the length of Europe in search protection. These images aroused in many viewers' minds the question: what is going on in Europe that these refugees are prohibited to catching trains, planes and buses like everyone else to arrive safely at their destinations?

As if the 2015-16 arrivals and their extensive mediatisation were not enough, the continuous loss of life though unsuccessful attempts to cross

$31<$ www.bbc.com/news/world-europe-58163073> accessed 2 November 2021.

$32<$ www.unhcr.org/news/press/2021/10/6172af254/unhcr-urges-states-end-stalemate -belarus-eu-border-avoid-further-loss-life.html> accessed 2 November 2021. 
the Mediterranean in unseaworthy boats has also been on front pages of news outlets around the world. Images of dangerous rescues, perilous attempts and figures of estimated deaths (far surpassing even the numbers of the US-Mexico border) published by IOM, have horrified readers and viewers in many countries. ${ }^{33}$ Additionally, the criminalisation of NGO rescue workers in particular in Italy including the highly mediatised prosecution of Carola Rakete, the German captain of a rescue ship operating in the Mediterranean, has not helped the image of the EU as an effective promoter of human rights particularly in the field of humanitarian rescue. ${ }^{34}$ Adding to the negative image, the fire at the refugee camp in Moria on the Greek island of Lesvos in September 2020 revealed to the world the degrading circumstances of life in the camp and the horror of non-existent reception facilities for thousands of vulnerable people after the fire. ${ }^{35}$

The plight of refugees and migrants seeking to arrive in Europe but blocked by national and EU funded border police has not made many friends for the EU. Roundly criticised by UNHCR on a regular basis, the treatment of refugees and migrants seeking protection and entry to the EU has also made its mark on regional and international human rights instances as well as at the UN more generally. The European Court of Human Rights has received a steady stream of cases regarding the treatment of refugees and migrants at EU external borders. ${ }^{36}$ The UN Human Rights Committee has received communications alleging violations of the International Covenant on Civil and Political Rights (for instance SDG v Italy filed in 2020) regarding the treatment and death of refugees and migrants in the Mediterranean. The Prosecutor of the International Criminal Court has received a detailed complaint in 2019 of crimes against humanity allegedly committed by EU and national officials in the support of the loosely termed Libyan border guards' treatment of migrants and

$33<$ https://missingmigrants.iom.int/> accessed 4 November 2021.

34 Nazzarena Zorzella and Monia Giovannetti, Ius migrandi: Trent'anni di politiche e legislazione sull'immigrazione in Italia (Franco Angeli 2020).

35 Vasileia Digidiki and Jacqueline Bhabha, 'EU migration pact fails to address human rights concerns in Lesvos, Greece' (2020) 22 (2) Health and Human Rights 291.

36 Galina Cornelisse, 'A new articulation of human rights, or why the European Court of Human Rights should think beyond Westphalian sovereignty' in MarieBenedicte Dembour and Tobias Kelly (eds), Are Human rights for migrants? (Routledge 2011) 113-134; Lieneke Slingenberg, 'The right not to be dominated: The case law of the European court of human rights on migrants' destitution' (2019) 19 (2) Human Rights Law Review 291-314. 
refugees. ${ }^{37}$ From the perspective of the regional and international judicial instances, European refugee and migration activities are taking up a lot of their time. And this is without counting the supervisory instances within the EU which have been engaged in investigating and determining legality of activities at the external borders in pursuit of deterring people from crossing them (see the numerous Fundamental Rights Agency reports, the April 2020 complaint to the EU Court of Auditors on the mismanagement of the Trust Fund for Africa regarding funding border activities, the Commission concerns about Frontex's expenditure of euros 100 million on drones used for pushbacks from Greece to Turkey October 2020 etc). ${ }^{38}$

The EU itself drew world attention to its battle against the arrival of (unwanted) persons by seeking a UN Security Council Resolution in 2015 to authorise military action against smugglers and traffickers of migrants in the Southern Central Mediterranean. Having achieved the objective of a UN Resolution, at least partially authorising military action in international waters, the EU failed dismally either to reduce the number of migrants missing in the Mediterranean (see IOM missing migrant data) ${ }^{39}$ or to stop the arrival of (unwanted) persons across the Mediterranean. According to Frontex's Annual Risk Analysis 2020, irregular sea border entries in 2019 totalled 106,246 while in the previous year the figure was 113,643. Other than the two exceptional years: 2015 and 2016 when substantially larger numbers of refugees and migrants arrived irregularly in the EU, the figure of irregular sea border entries has rarely exceeded 200,000. The EU's military operation in the Mediterranean has been quietly brought to a close. ${ }^{40}$ It remains, however, an outstanding example of the EU intentionally raising border control from an interior ministry issue to one of high politics within a very public venue, the UN.

The Commission's New Pact on Migration and Asylum (COM 609(2020)) issued in September 2020 reflected this conundrum facing EU policy makers. In section 6 entitled 'working with our international partners' it seeks to plot a route to engaging countries outside the EU both

$37<$ www.statewatch.org/media/documents/news/2019/jun/eu-icc-case-EU-Migration -Policies.pdf $>$ accessed 4 November 2021.

38 Luisa Marin, 'Is Europe turning into a "technological fortress"? Innovation and technology for the management of EU's external borders: Reflections on FRONTEX and EUROSUR' in Michiel A. Heldeweg and Evisa Kica (eds), Regulating Technological Innovation (Palgrave Macmillan 2011) 131-151.

39 (n 33).

$40<$ https://moderndiplomacy.eu/2020/02/20/the-ending-of-operation-sophia-the-eu-s way-from-its-human-security-approach/> accessed 4 November 2021. 
bilaterally and regionally in regulating migration towards the EU which deliver what the Pact promises will be 'mutual benefits.' However, there is a profound difficulty at the heart of the Pact's approach in particular for countries outside the EU. The objective of the Pact as stated in this section is 'to address the complex challenges of migration and its root causes to the benefit of the EU and its citizens, partner countries, migrants and refugees themselves.'

On the one hand this formulation completely fails to take into account that the 'migrants and refugees' referred to are in fact the citizens of those same third countries with which the EU seeks to address the challenges. The only specified citizens are EU citizens, giving the impression that other countries do not have citizens they only have prospective migrants and refugees as their inhabitants. On the other hand, by placing border control in the hands of other states which are directed to prevent (unwanted) persons from moving towards the EU, through high politics, ${ }^{41}$ the EU has made itself very vulnerable to migration diplomacy where third states can use the threat of failing to stop (unwanted) movement of persons towards the EU to achieve political objectives in other fields. By allowing border control and migration to be sensationalised internally, many EU states have placed themselves in an impossible situation as regards other countries. The excessive investment of state sovereignty in "effective" border controls on persons has had the unwanted political outcome of weakening their general political position vis-à-vis third states.

\section{The International Relations Problem}

From a more principles position in international relations, the Pact fails to take a rounded perspective of the issue of migration. All migrants are citizens of some country (except the very few who are stateless). Just as the EU seeks to defend the interests of its citizens, so other states are required to do so as well. The constitutions of countries around the world generally express the duty of the state to act in the interests of the citizens. Images of the poor treatment of people at EU borders as perceived from within the EU are images of migrants and refugees. But in other countries around

41 Naoko Shimazu, 'Places in diplomacy' (2012) 31 (6) Political Geography 335-336; Øyvind Svendsen and Rebecca Adler-Nissen, 'Differentiated (Dis)integration in Practice: The diplomacy of Brexit and the low politics of high politics' (2019) 57 (6) Journal of Common Market Studies 1419-30. 
the world, these are images of their citizens suffering degradation and humiliation by EU and Member State actors and actions. ${ }^{42}$ The more mediatised the EU treatment of migrants and refugees, the more problematic the question of cooperation in pursuit of EU migration goals becomes for the governments of other countries. The Pact recognises the issue at least obliquely when it states "[i]t is important to bear in mind that migration issues such as border management or more effective implementation of return and readmission can be politically sensitive for partners." This is perhaps an understatement.

The Pact is quite opaque about how to leverage migration management cooperation as considered desirable by the Commission and Member States in the context of partnerships with third countries. It calls for the incentivization and improvement of expulsion (and readmission by third states) through the instrumentalization of other policy areas of interest to third countries, a carrot and stick approach. In the EU's politics of sticks and carrots, the stick is primarily how to convince third states enthusiastically to embrace EU expulsions of the third state's citizens. In light of EU Member States experience with Belarus, Libya and Turkey, this might seem both cynical and naive simultaneously. It is cynical from the perspective of human rights protection where the objective of getting other states to prevent arrivals of (unwanted) persons will inevitably also prevent refugees from arriving and seeking durable protection. It is naïve from the perspective that the policy, accompanied by EU Member States internal political investment of state sovereignty in border controls and preventing the arrival of (unwanted) persons as rendered them highly vulnerable to these same third states. If these third states do not prevent arrivals, as a result of Member State internal sensitivity to effective border controls, a political panic can be the result. The numbers of (unwanted) people arriving may be miniscule - a few hundred - but the internal political reaction may verge on the hysterical. ${ }^{43}$

42 Diego Acosta Arcarazo, 'The good, the bad and the ugly in EU migration law: is the European parliament becoming bad and ugly? (The Adoption of Directive 2008/115: the Returns Directive)' in Elspeth Guild und Paul Minderhoud (eds), The First Decade of EU Migration and Asylum Law (Brill Nijhoff 2011) 179-205.

43 See for example the letter of twelve Member States to the Commission Vice-President of 7 October 2021 (n 27). 


\section{The Difficulty of Delivering Benefits}

The EU 'carrots' to achieve third countries' acceptance of EU migration objectives vary but better access for nationals of third countries to the EU for economic purposes is an evergreen. It turns up in the Pact in the form of talent partnerships to enhance commitment to support legal migration and mobility with key partners. This is reminiscent of the mobility partnerships developed in the 2010s to encourage southern Mediterranean states, in particular, to accept readmission agreements. A good example is the mobility partnership signed by the EU with Morocco in 2013. But implementation proved embarrassing. In 2010, 10,416 Moroccan seasonal workers entered the EU (according to the Commission's data). By 2016 the number had dropped to 3,781. Regarding entry for other remunerated activities, the data shows that while in 2010 43,334 Moroccans entered the EU in this category by 2016 the number had dropped to 6,283 (data on file with the author). These figures cast doubt on the good faith of the EU and Member States in offering enhanced employment opportunities for Moroccans in return for cooperation on border management and expulsion. The experiences of the mobility partnerships are unlikely to convince any third states that talent partnerships will result in enhanced opportunities for their citizens.

Finally, in the carrot and stick category, the Pact heralds the changes to the Visa Code which introduced a link between access to Schengen visas and the costs thereof and states' readmission practices regarding their citizens being expelled from EU states. This linkage has been criticised as not only unfair to visa applicants who cannot be held responsible for the actions of their fellow citizens but also as likely to be counterproductive creating inequalities among states in the same region regarding access to visas and thus fostering sentiments of injustice in those which are disadvantaged. ${ }^{44}$ While the European Parliament achieved a softening of the proposal, turning it from a coercive measure to one where advantages accrue to states which cooperate with the EU, the establishment of the principle is unlikely to contribute to good international relations. Here it is directly citizens of the third state who are affected not third country national transiting the state.

44 Salvatore Fabio Nicolosi, 'Refashioning the EU Visa Policy: A New Turn of the Screw to Cooperation on Readmission and to Discrimination?' (2020) 22 (4) European Journal of Migration and Law 467-491. 
The international relations weakness of the Pact is, no doubt, a reflection of flaws in the EU structures around foreign policy, international relations and diplomacy. This is not least the result of the late arrival of the competence for foreign affairs and external action in the EU in the field (2009) and the strength of national foreign ministries, still jealously guarding their powers. Additionally, the international relations field in EU law remains very divided regarding the exercise of international relations powers by different Directorates General in the Commission. For example, the negotiation of trade agreements is firmly within the competence of DG Trade which, proudly on its webpage, gives first place to these developments. In contra-distinction with international relations, the strength of interior ministries as regards migration and asylum has grown since the transfer of competence in 1999 (though formal cooperation began with the Maastricht Treaty in 1992). The tensions between DG Home and DG Trade regarding the 'mainstreaming' of migration objectives in international relations is often demonstrated in Brussels by the absence of representatives of DG Trade at meetings called by DG Home on this subject, of course always accompanied by apologies and reasons regarding other obligations. Institutionally the interior ministry weight in Brussels in relation to its international relations counterpart is reflected by the existence of a DG Home, very occupied by migration and asylum issues. But for international relations there is only a body, the European External Action Service (EEAS), with divided loyalties between the Commission and the Council. As almost an afterthought, the Pact mentions that close cooperation with the High Representative will be important.

\section{Conclusions}

The outcome for the EU of this preponderance of DG Home and interior ministry perspectives on migration and asylum in an international context is the presentation in the Pact of 'citizens' as exclusively EU nationals and all other people as migrants or potential migrants even when the Pact is promoting collaboration with third countries. This weakness is not inevitable but to change it will require a rebalancing of the EU institutions and their priorities to privilege good relations with third states, including the citizens of third states who determine the composition of their governments. The influence of the DG Home and interior ministry perspectives that nationals of other countries are primarily sources of threat in the form of illegal immigration which needs to be 'addressed' in the states where 
they are present (ie their states of citizenship) will, inevitably, defeat the objective of cooperation with third states in most cases.

Equally problematic is the weaponizing of border controls by unscrupulous leaders of neighbouring states. The excessive EU Member State investment of state sovereignty in border controls to prevent arrivals of (unwanted) people has provided a rich new area for discussions with the Member States on areas of choice of those third state leaders. The way in which some Member States have permitted the arrival of even small numbers of (unwanted) people into their country to create a political and media panic has weakened their position in international relations. A consequence of this politicisation of border controls is that any apparent failure results in newspaper/media headlines, questions in Parliament and demands from opposition parties and various lobby groups for more "effective" action. The political claim that the state controls borders regarding movement of persons is no longer accepted as a rhetorical or theoretical statement but rather something which state officials in power have promised to deliver. Failure to do so makes them politically vulnerable internally resulting in external vulnerability through the dependency on neighbouring countries to prevent movement. All of this takes place notwithstanding evidence provided even by Frontex itself that there are practical limitations to border controls on persons, for instance the fact that at the best of times and under the most controlled circumstances border police have only twelve seconds to decide on the entry of an individual at an external border crossing point. ${ }^{45}$

$45<$ https://frontex.europa.eu/assets/Publications/General/12_seconds_to_decide.pd $f>$ accessed 4 November 2021. 